\title{
Preface - hope for the future?
}

I have an abiding interest in money laundering. I hasten to add that this is purely for professional, personal and academic reasons.

My professional interest arose from my time when I served as Chief Mutual Legal Assistance Officer (CMLAO) at the Commonwealth Secretariat (ComSec) in London. This gave me my first introduction to the Financial Action Task Force (FATF), to its meetings at the OECD in Paris and to the Forty Recommendations which have shaped and continue to shape the global anti-money laundering response.

A recognition of the need to support Commonwealth members to develop their international co-operation capacity had already led Commonwealth Heads of Government to agree to two Commonwealth schemes to assist member states with model legislation designed to facilitate extradition and mutual legal assistance arrangement inter se. These are the London Scheme for Extradition within the Commonwealth and the Harare Scheme on Mutual Assistance in Criminal Matters. Recognising the need to assist them to comply with their anti-money laundering (AML) obligations set out in the FATF Recommendations, part of my role as CMLAO was to help draft a 'model' money laundering law (or AML law - we could never agree on the title) for Commonwealth members. This work provided me with some vital insights into the development of practical and effective AML legislative provisions. The model law proved useful, with many Commonwealth members using it as a basis for introducing their first anti-money laundering legislation. The Commonwealth continues to do fine work in supporting members in technical assistance in the area of international cooperation.

Having lived and worked in Zambia and Zimbabwe and written on African issues for so long, I have witnessed the appalling impact of the abuse of power, corruption and money laundering by many political leaders on members of my extended family as well as on the lives of millions of ordinary people. Yet I also recognise that there are so many committed public officials who seek every day to carry out their responsibilities honestly and honourably and I take pride that so many of my former students from the University of Zambia and University of Zimbabwe are continuing to do so. The need for effective action is the catalyst for this book. In essence it takes the position that what is needed is not despair but the development of effective strategies both domestically and 
transnationally to bring hope for a better and more prosperous future for the victims of the greed of political leaders.

In 2011, I was appointed to a Chair in Law at the University of Buckingham. This gave me the opportunity to develop a new LLM course entitled 'Money Laundering, Off-shore Banking and Asset recovery'. My students came from a diverse range of jurisdictions and fell into three categories. There were those from the 'victim' states for whom the laundering of the proceeds of corruption by political leaders was a fact of life. For them, understanding how to combat money laundering was a priority. Several others came from off-shore jurisdictions such as the British Virgin Islands and the Cayman Islands whose economies have flourished thanks to the strong and vibrant financial sector facilitated by the secrecy that is maintained over bank accounts, companies and trusts. Their approach was very different: 'We are doing very nicely thank you very much and have no wish to alter the present arrangements.' The UK students often took the view that money laundering was not a local but a developing world problem. It was not until they realised that the UK is a money laundering centre as well as a 'safe-haven' state in which corrupt political leaders (amongst others) make use of the financial institutions for laundering purposes, as well as to use their proceeds of crime to purchase real estate and the like, that they understood the reality. I was able to emphasise this a few years later thanks to the words of President of Nigeria, Muhammadu Buhari. At a reception prior to a major international conference on corruption in London in 2016, the then UK Prime Minister, David Cameron, was overheard describing Nigeria as 'very corrupt'. At the Anti-Corruption conference the following day, I was sitting in the front row of the audience when President Buhari gave his keynote address. He was then asked about the Cameron comment. His response was simple: 'Give us back our money'.

In writing this book, I have encountered a few problems concerning terminology. Do I refer to 'states', 'countries' or 'jurisdictions'? The United Nations Convention against Corruption (UNCAC) and the African Union Convention on Preventing and Combating Corruption (AU Convention) both refer to 'State Parties' and 'states' whilst the FATF refers to 'countries'. Some of the most significant off-shore centres linked with facilitating money laundering such as the British Overseas Territories are neither but rank as separate 'jurisdictions', for example, for the purposes of international cooperation arrangements. I have therefore used the most appropriate term throughout the book.

A similar problem has arisen concerning references to private sector entities. Once again these are referred to using a range of terms. In the UNCAC the term 'legal persons' is adopted but without a definition. Article 1 of the AU Convention refers to the 'Private sector' as meaning the 'sector of a national economy under private ownership ... and other sectors of the economy not under the public sector or the government'. The FATF Recommendations use 
the term 'legal persons' to include 'companies, bodies corporate, foundations, anstalt, partnerships or associations and other relatively similar entities'. Given this choice, I have felt it safe to use whichever is the most useful term in the particular context.

I am well aware that seeking to adopt a pan-African approach to the subject is very ambitious. I make no apology for this. Money laundering by political leaders is a continent-wide problem and requires a continent-wide response. The FATF Recommendations provide the basis for doing so. Of course, it is not possible (or indeed necessary) to explore the position in every African country and whilst I have included a range of examples of good and bad practice, I realise that there are some I have overlooked. Hopefully, the book will also provide a catalyst for developing new and effective means of sharing good practice and experiences for all those dedicated to combating the money laundering evil.

I have sought to state the position as at 30 March 2020. Events move quickly in this area and I have endeavoured to include new developments that command inclusion, the Airbus affair and the impact from the publication of the Luanda Papers being just two prime examples.

As ever, my deepest love and thanks to my wife Trinah and to my children Shamiso and Simbi for all their support, assistance and patience.

Professor John Hatchard Buckingham Law School

30 March 2020 